\title{
The Effect of Word-Of-Mouth on Consumer Emotions and Choice Findings From a Service Industry
}

\author{
Martensen, Anne; Grønholdt, Lars
}

Document Version

Accepted author manuscript

Published in:

International Journal of Quality and Service Sciences

DOI:

10.1108/IJQSS-04-2016-0037

Publication date:

2016

License

Unspecified

Citation for published version (APA):

Martensen, A., \& Grønholdt, L. (2016). The Effect of Word-Of-Mouth on Consumer Emotions and Choice:

Findings From a Service Industry. International Journal of Quality and Service Sciences, 8(3), 298-314.

https://doi.org/10.1108/IJQSS-04-2016-0037

Link to publication in CBS Research Portal

\section{General rights}

Copyright and moral rights for the publications made accessible in the public portal are retained by the authors and/or other copyright owners and it is a condition of accessing publications that users recognise and abide by the legal requirements associated with these rights.

Take down policy

If you believe that this document breaches copyright please contact us (research.lib@cbs.dk) providing details, and we will remove access to the work immediately and investigate your claim. 


\section{The Effect of Word-Of-Mlouth on Consumer Emotions and Choice: Findings from a Service Industry Anne Martensen and Lars Gronholdt}

Journal article (Post print version)

CITE: The Effect of Word-Of-Mouth on Consumer Emotions and Choice: Findings from a Service Industry. / Martensen, Anne; Gronholdt, Lars. In: International Journal of Quality and Service Sciences, Vol. 8, No. 3, 2016, p. 298-314.

This article is ( $)$ Emerald Group Publishing and permission has been granted for this version to appear here: http://research.cbs.dk/en/publications/the-effect-of-wordofmouth-on-consumeremotions-and-choice(740d80f6-1908-4d15-8bc2-fef66dc4e89a).html.

Emerald does not grant permission for this article to be further copied/distributed or hosted elsewhere without the express permission from Emerald Group Publishing Limited.

Uploaded to Research@CBS: May २०17 


\title{
The effect of word-of-mouth on consumer emotions and choice: Findings from a service industry
}

\author{
Anne Martensen and Lars Grønholdt \\ Department of Marketing, Copenhagen Business School, Denmark
}

\begin{abstract}
Purpose - The purpose of this paper is to examine how received word-of-mouth (WOM) influences consumer emotions and, in turn, behavioral attitude and intention.

Methodology/approach - A conceptual model is developed by extending the theory of reasoned action framework to include WOM and emotions. The conceptual model is operationalized through a structural equation model, and the model is estimated and tested by using the partial least squares method. A survey among 509 consumers in Denmark forms the empirical basis for the study.
\end{abstract}

Findings - The study finds that positive and negative WOM has an asymmetric influence on emotions, behavioral attitude, and intention, i.e. that consumers respond differently to positive and negative WOM. The study also finds that positive WOM has a larger impact than the social norm on behavioral attitude and intention and that negative WOM has an impact equal to that of the social norm. Furthermore, the study finds that emotions are an important mediator for both WOM and social norm.

Research limitations - The study is limited to a large travel agency in Denmark.

Practical implications - This study has clear implications in terms of measuring the importance of WOM and emotions in consumer decision-making. It may serve as a useful basis for a practical WOM marketing strategy, which is a critical and increasingly applied element of customer-focused companies' marketing strategies.

Originality/value - This paper provides new insights into how WOM works and the interplay between WOM, emotions, and social norm in consumer decision-making.

Key words Word-of-mouth, Emotions, Social norm, Behavioral attitude, Behavioral intention; Structural equation modeling

Paper type Research paper 


\section{Introduction}

Word-of-mouth (WOM), i.e. consumer-to-consumer communication, has been at the center of great attention from researchers and practitioners for many years. A growing influence of WOM has been demonstrated through extensive research (Allsop et al., 2007; Bruyen and Lilien, 2008; Martensen and Mouritsen, 2014; Prendergast et al., 2010; Voyer and Ranaweera, 2015). Also, practitioners have shown an interest in measuring WOM conversations and the power of WOM (Bughin et al., 2010; Keller, 2007; Keller and Fay, 2012). According to an analysis by McKinsey \& Company, "slightly more than two-thirds of the U.S. economy has been influenced by" WOM (Dye, 2000, p. 140).

WOM is generally regarded as the informal exchange of purchase-related, consumptionrelated, and experience-related information between consumers (Chu and Kim, 2011; HennigThurau et al., 2004; Söderlund and Rosengren, 2007). WOM can be positive (PWOM) or negative (NWOM). PWOM encourages brand choice and is expected to affect consumer responses positively, while NWOM discourages brand choice and is expected to have a negative influence (Anderson, 1998; Bruyn and Lilien, 2008; Gildin, 2002).

The purpose of this study is to provide an extension of the classic and widely used theory of reasoned action (TRA) model by adding WOM (both PWOM and NWOM) and emotions (both positive and negative emotions). The relevance and importance of this approach are that it will reveal the influence of WOM compared to the influence of social norm. It will also demonstrate consumers' responsiveness to PWOM as well as NWOM on emotions, behavioral attitude, and intention. Finally, the study will investigate the role of including emotions as a mediator for WOM and social norm.

The study seeks to fill several research gaps argued for in the literature. First, WOM has long been recognized as having a powerful influence on the consumer buying-decision process (Bansal and Voyer, 2000; Bone, 1995; Dye, 2000; Mangold et al., 1999; Wagenheim, 2005). However, only a limited number of studies have focused on "what happens when WOM is received or on the conditions in which WOM will be most effective in enhancing a receiver's perceptions or actions" (Sweeney et al., 2008, p. 344). Also Bone (1995) and Brown and Reingen (1987) call for more research on the influence of WOM on the receiver. Thus, this study will focus on the receiver of WOM.

Second, several studies have examined how the well-recognized consumer behavior Theory of Reasoned Action (TRA) (Ajzen, 1991; Ajzen and Fishbein, 1980; Fishbein and Ajzen, 1975) can be extended to improve the explanatory power of behavioral intention (e.g., Conner and Armitage; Langdridge et al., 2007; Martensen and Mouritsen; 2014). We will contribute to this consumer research stream.

The TRA proposes that a consumer's behavioral intention depends on the consumer's behavioral attitude and social norm. The attitude towards the behavior is "the general feeling of favorableness or unfavorableness for that behavior" (Kotler et al., 2012, p. 280). Social norm refers to the consumer's "perceived opinion of other people in relation to the behavior in question" (Kotler et al., 2012, p. 280), i.e., perception of social pressure from significant others to perform, or not to perform, a certain behavior (Ajzen, 1991; Langdridge et al., 2007). The social norm is created in a social context, and WOM is interpersonal communication in a social context. The social influence thus operates through both social 
norm and WOM. How do these two social phenomena work simultaneously? What are the relative influences of social norm and WOM? These questions will be answered by extending TRA by WOM.

Third, Hansen (2005), Shiv and Fedorikhin (1999), and Weber et al. (1998) state that consumers may use multiple approaches to their decision processes, i.e., both a cognitive and an affective approach, which have to be reflected in the models that attempt to describe such a process. TRA is limited by looking only at the consumer's rational and cognitively driven evaluation of buying intention and behavior, leaving out the emotional influence on behavior. Eagly and Chaiken (1993) point out that affect and attitude are two distinct concepts. As a result, Perugini and Bagozzi (2001) have suggested an extension of the theory of planned behavior in which emotions are included. Based on this discussion, we include emotions in the extended TRA model. However, no previous study has focused on how WOM and social norm influence the receiver's emotions. The question is: Is it relevant to include emotions as a mediator for WOM and social norm when studying a receiver's behavioral attitude and intention?

Last, the central issue of how to put all the pieces of important knowledge together remains in dispute. Previous research has studied the elements separately, but the question of how to draw up a holistic framework is still unsolved. We will focus on such a simultaneous estimation and test of the proposed conceptual model. As Langdridge et al. (2007, p. 1889) state: "A simultaneous test is important (a) to ensure that all of these additional variables are conceptually distinct from each other, and (b) to determine which additional variables, if any, qualify as additional predictors in the TRA".

\section{Conceptual model and hypotheses development}

To study the influence of WOM and social norm on emotions, behavioral attitude, and intention, we develop and empirically test the conceptual model shown in Figure 1. Some of the hypotheses proposed have been investigated thoroughly by other researchers, for instance, the relationships between behavioral attitude, intention, and social norm in the TRA model (e.g., Ajzen, 1991; Ajzen and Fishbein, 1980; Fishbein and Ajzen, 1975; Godin and Kok, 1996; Kim and Hunter, 1993; Sheeran and Taylor, 1999). Therefore, further elaboration is not necessary for the well-documented TRA hypotheses depicted in the right-hand side of Figure 1:

H1: Behavioral attitude has a positive effect on behavioral intention

$H 2 d$ : Social norm has a positive effect on behavioral intention

Some TRA studies also include a path from social norm to behavioral attitude, which has improved the predictive power of behavioral intention (e.g., Hansen et al., 2004; Langdridge et al., 2007). Thus:

H2c: Social norm has a positive effect on behavioral attitude

In the following, we will discuss WOM and emotions, as well as the relationships that can be hypothesized between these and the TRA variables in the model. 


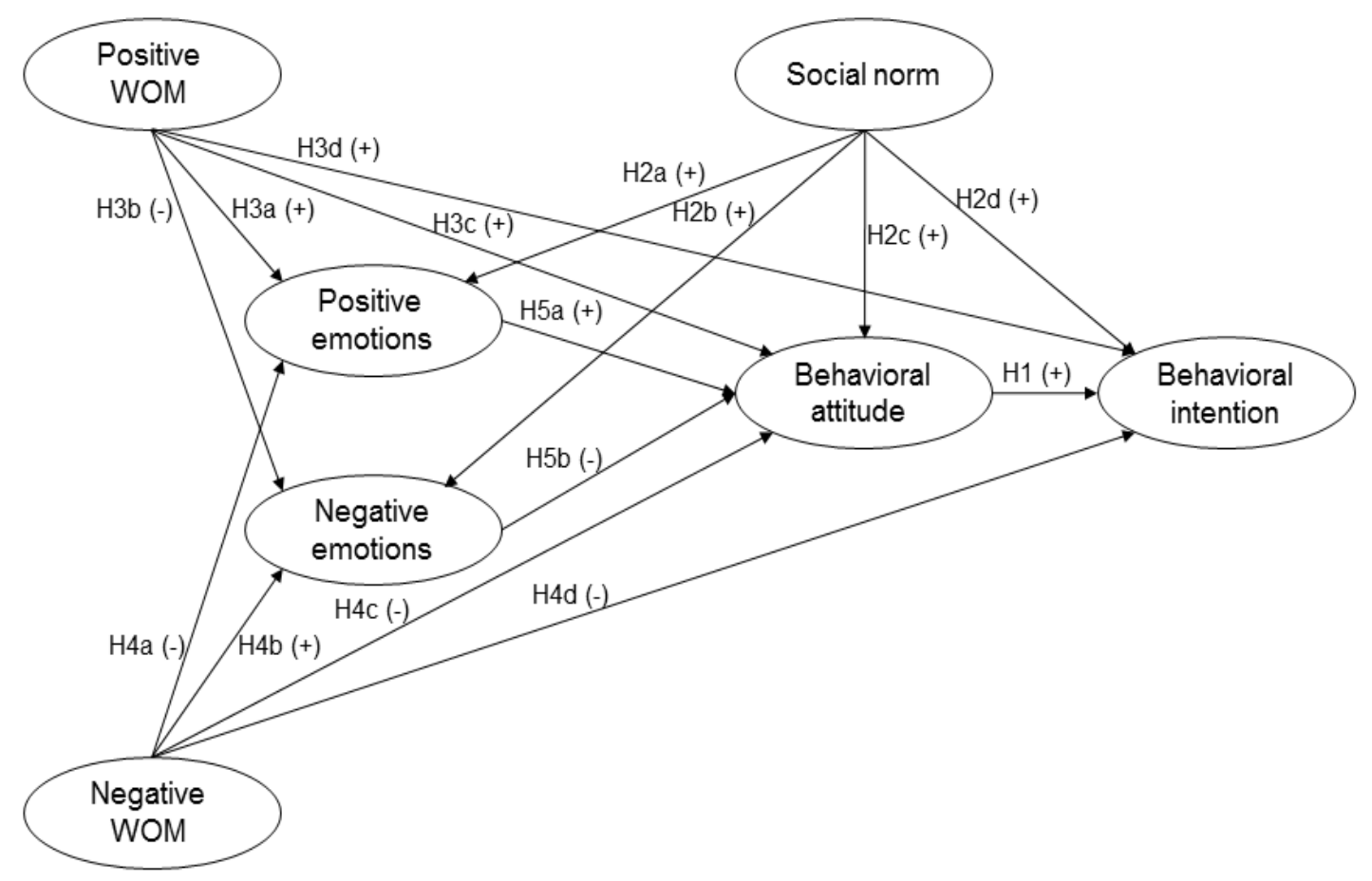

Figure 1. The conceptual model

\section{Positive and negative WOM}

Previous research shows that consumers respond positively to PWOM and negatively to NWOM, however asymmetrically. Some researchers argue that consumers are more prone to believe negative than positive information, which indicates that NWOM is more powerful than PWOM. For example, most brand messages tend to be positive, but when negative information distorts positive messages, it often attracts attention (Chakravarty et al., 2010). This asymmetry is supported by the accessibility-diagnosticity theory (Fiske, 1980), the prospect theory (Kahneman and Tversky, 1979), and several empirical studies (Arndt, 1967; Burzynski and Bayer, 1977; Chevalier and Mayzlin, 2006; East et al., 2007; Fiske, 1980; Laczniak, 2001; Mizerski, 1982; Wright, 1974).

Other researchers argue that based on theories of brand loyalty and familiarity, PWOM has a greater influence on consumer response than NWOM. Well-known and well-established brands are characterized by customers preferring one specific brand to others and being highly satisfied and loyal to that brand. Satisfied and loyal customers are more likely to propagate and engage in PWOM about the brand and the customer experience, since PWOM confirms the consumer's current choice of brand and leads to a state of mental balance (Ahluwalia, 2002; Godes and Mayzlin, 2004). Loyal consumers may be less likely to accept or notice 
NWOM about the brand, since this contradicts previous beliefs, attitudes and behavior and leads to a state of mental imbalance.

Yet other researchers find that the impact of PWOM and NWOM on consumers' brand attitudes and purchase intentions are of roughly the same size (Ahluwalia, 2002; Ahluwalia et al., 2000; Charlett and Garland, 1995).

Hence, previous research lacks general conclusions about the asymmetrical direction of PWOM and NWOM influence on consumer responses. In our empirical study, we investigate a well-established service industry (travel agencies) and a well-known company, where loyalty tends to be high, which is why we expect that PWOM will have a stronger influence than NWOM on behavioral attitude and intention.

Based on this discussion we investigate whether an asymmetric influence of WOM on behavioral attitude and intention exists. We hypothesize that the receiver of WOM deals with PWOM and NWOM in different ways.

Bristor (1990, p. 58) emphasizes that "what is also needed is to examine the effect of WOM on cognitions and affect". Even though this was emphasized more than two decades ago, we are not aware of any research that studies how WOM influences consumers' emotions.

The above discussion leads to the following hypotheses:

H3a: PWOM has a direct positive effect on positive emotions

$H 3 b$ : PWOM has a direct negative effect on negative emotions

$H 3 c$ : PWOM has a direct positive effect on behavioral attitude

$H 3 d$ : PWOM has a direct positive effect on behavioral intention

$H 4 a$ : NWOM has a direct negative effect on positive emotions

$H 4 b$ : NWOM has a direct positive effect on negative emotions

$H 4 c$ : NWOM has a direct negative effect on behavioral attitude

$H 4 d$ : NWOM has a direct negative effect on behavioral intention

\section{Social norm}

It is natural and interesting to compare the normative (social norm) and informative (WOM) influence in the extended TRA model. This requires that WOM and social norm influence emotions, behavioral attitude, and intention in similar ways, i.e., that they have similar relationship structures.

Therefore:

$H 2 a$ : Social norm has a direct positive effect on positive emotions $H 2 b$ : Social norm has a direct positive effect on negative emotions $H 2 c$ : Social norm has a direct positive effect on behavioral attitude $H 2 d$ : Social norm has a direct positive effect on behavioral intention 


\section{Emotions}

The literature has eagerly discussed whether emotional responses are a function of cognition, or emotional responses affect cognition. According to Du Plessis (2005), emotions are the first part of a rational decision caused by more neuron connections flowing from the emotional part of the brain to the rational part of the brain than the other way around. This is also supported by Ajzen (2002), Martensen et al. (2007), Martensen and Grønholdt (2008), Zajonc (1980) and Verplanken et al. (1998).

Previous research argues for a separation of emotions into a positive and a negative dimension (e.g., Babin, Lee, Kim and Griffin, 2005; Dubé-Rioux, 1990; Hansen, 2005; Kim and Griffin, 2005; Liljander and Strandvik, 1997; Phillips and Baumgartner, 2002). We will follow these recommendations in our analysis of how emotions drive behavioral attitude, and separate emotions into a positive and a negative dimension. This leads to the following hypotheses:

H5a: Positive emotions have a direct positive effect on behavioral attitude

$H 5 b$ : Negative emotions have a direct negative effect on behavioral attitude

The 15 proposed hypotheses are illustrated by the links in Figure 1.

\section{Methodology}

\section{Measures development}

The conceptual model's seven variables are viewed as latent variables, which are measured by three to six measurement variables or items based on scales established in academic literature.

To measure PWOM and NWOM, the scales developed by Bansal and Voyer (2000) and Murray and Schlacter (1990) are used. The emotion items are based on Hansen (2005) and Hansen and Christensen (2007). The social norm measures are operationalizations of different facets derived from Hansen (2008), Hansen et al. (2004), and Langdridge et al. (2007). The behavioral attitude scale used for this study is adapted from Martensen et al. (2007) and Spears and Singh (2004). The measurement of behavioral intention is based on Martensen et al. (2007) and Putrevu and Lord (1994).

All items are generic, which means they are formulated in such a flexible manner that they can be used across companies and industries. The developed questionnaire consists of 36 items listed in the Appendix.

\section{Data collection}

A professional market research agency has collected data by means of an online panel survey with persons between the ages of 18 and 60 years. The case studied is one of the largest travel agencies in Denmark, Star Tour. All respondents were familiar with this travel agency and were told positive or negative things about the agency from families, friends, acquaintances, colleagues, neighbors, etc. A total of 509 valid interviews were conducted, and a representative sample was obtained. 


\section{Analytical approach}

The conceptual model in Figure 1 is operationalized as a structural equation model (SEM) which links each latent variable with the corresponding measurement variables (the measurement model) and links the latent variables through causal relationships (the structural model) symbolized by the arrows in Figure 1. All measures are reflective.

The data were analyzed using the partial least squares approach to structural equation modeling (PLS-SEM) that simultaneously estimates the measurement and the structural model by maximizing the explained variance of the dependent latent variables (Hair et al., 2011), which is contrary to covariance-based SEM (CB-SEM) (Hair et al., 2011). This means that PLS-SEM does offer advantages for predictive purposes (Fornell and Cha, 1994; Hair et al., 2011). PLS-SEM places minimal restrictions on sample size, measurement scales, and data distributional assumptions (Hair et al., 2011), and it is robust (Cassell et al., 1999; Chin, 1998; Fornell and Bookstein, 1982; Hair et al. 2012; Hulland, 1999). Furthermore, PLS-SEM is especially suited for exploratory research, theory development, and complex models (many latent and measurement variables) (Hair et al., 2011), such as the current study. Therefore, we have chosen the PLS-SEM method.

We followed the recommended two-stage analytical procedure for PLS-SEM (Fornell and Larcker, 1981; Hair et al., 2012; Hulland, 1999): First, the measurement model (also called the outer model) was evaluated, then the structural model (also called the inner model) was evaluated, including estimation and testing of the model. In both stages we used the software SmartPLS (Ringle et al., 2005), which has become an increasingly applied tool to analyze structural equation models.

\section{Results}

\section{Measurement model evaluation}

We examined the reliability and validity of the scales. First, item reliability is normally established if the factor loading of an item is 0.7 or more (Carmines and Zeller, 1979; Hair et al., 2011; Hulland, 1999). We found from the SmartPLS output that the lowest loading was 0.72 , i.e. greater than the 0.7 threshold, and 32 of the 36 item loadings were 0.8 or above. This indicates that item reliability was very satisfactory for all latent variables.

Second, composite reliability (internal consistency) was assessed using the composite reliability coefficient recommended by PLS researchers, and acceptable level is said to be 0.7 or higher (Baumgartner and Homburg, 1996; Chin, 1998; Fornell and Larcker, 1981; Hair et al., 2011; Hulland, 1999). We found that all composite reliability coefficients were greater than 0.9 and clearly exceed the recommended threshold. In addition, we also used the average variance extracted (AVE), which should be greater than 0.5 (Chin, 1998; Fornell and Cha, 1994; Fornell and Larcker, 1981; Hair et al., 2011). The AVEs for all latent variables exceed this condition, since the lowest reported AVE value was 0.67 , demonstrating composite reliability for all latent variables also in this way.

Third, discriminant validity is present if the square root of AVE of a latent variable is larger than its correlations with the other latent variables (Fornell-Larcker criterion) (Chin, 1998; 
Fornell and Larcker, 1981; Hair et al., 2011; Hulland, 1999). This criterion was met for all latent variables, which indicates that the latent variables in the model are distinct from each other.

Thus, with acceptable reliability and validity assessments our measures were considered to be appropriate for subsequent estimation and test of the causal model.

\section{Structural model evaluation}

The PLS estimation was carried out by including all hypothesized relationships in Figure 1 and testing these relationships at the conventional 0.05 level of significance (one-sided) by using t-values obtained from the bootstrap re-sampling procedure. One insignificant relationship (from NWOM to behavioral attitude) was removed, and the model was reestimated and tested. The final estimated model with estimated path coefficients $(\beta)$ and their significance is illustrated in Figure 2, showing that all these path coefficients have signs as expected and are statistically significant (all $\mathrm{t} \geq 2.12, \mathrm{p} \leq 0.017$, one-sided).

To evaluate the PLS model, $\mathrm{R}^{2}$ values for the endogenous latent variables are examined (Chin, 1998; Hair et al., 2011; Hulland, 1999), which for positive and negative emotions are respectively 0.47 and 0.42 , and for behavioral attitude and intention are respectively 0.70 and 0.76. According to Hair et al. (2011), these $\mathrm{R}^{2}$ values can be described as moderate for emotions and substantial for behavioral attitude and intention. Overall, these explanatory powers indicate good overall model fit.

In conclusion, the quality of the model is good with substantial explanatory power. Thus, there is great certainty and precision in the results and conclusions to be drawn from the study. 


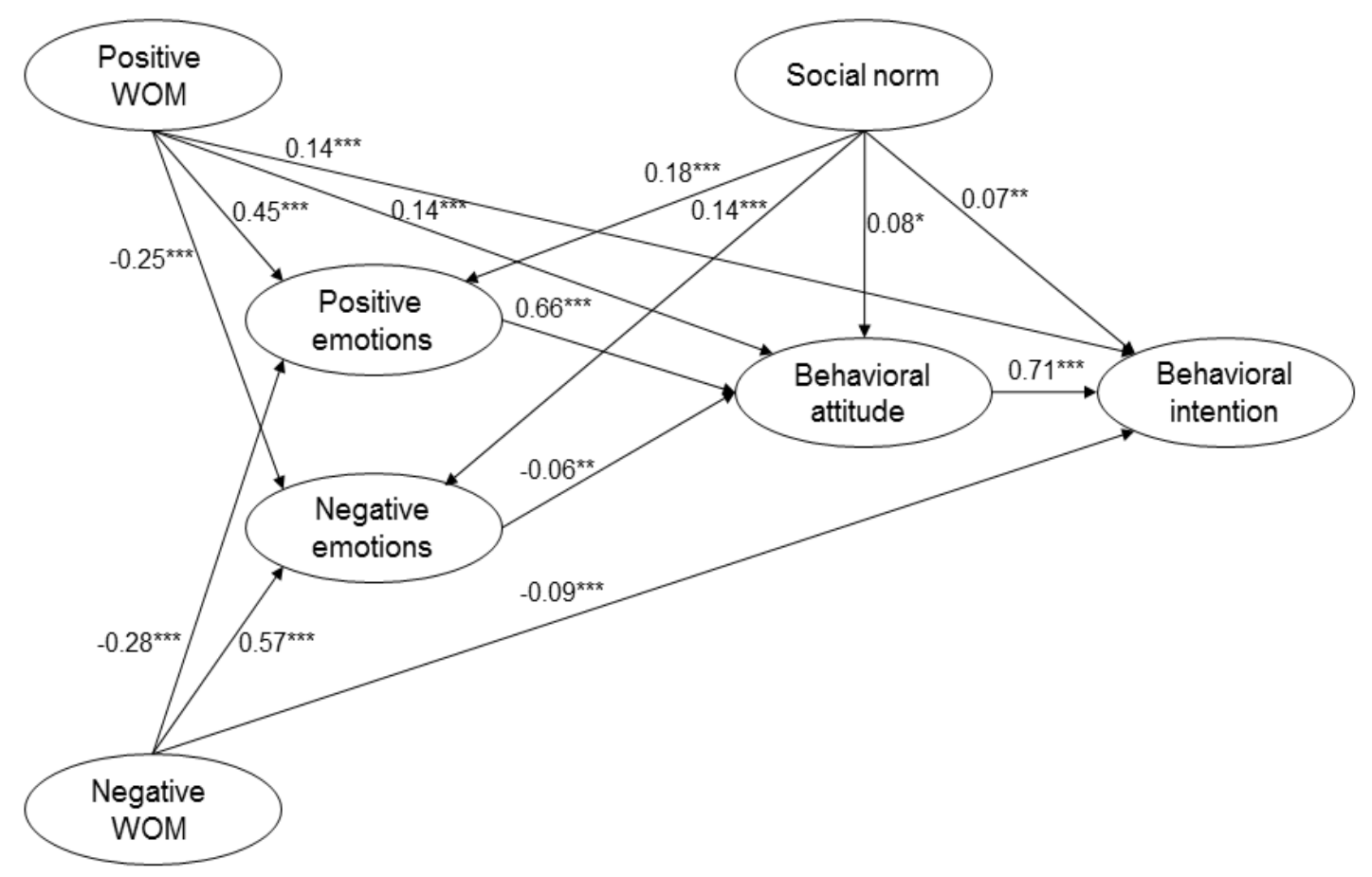

Note: Numbers on the arrows are estimated path coefficients $(\beta)$.

$* \mathrm{p}<0.05, * * \mathrm{p}<0.01, * * * \mathrm{p}<0.001$, one-sided.

Figure 2. The estimated model

\section{Discussion and practical implications}

It appears from Figure 2 that 13 hypotheses are accepted (all $\mathrm{p} \leq 0.017$ ) and only one hypothesis is rejected, namely $\mathrm{H} 4 \mathrm{c}(\mathrm{p}>0.05)$, which we will comment on in the following section. In general, the findings clearly indicate the relevance of including WOM and emotions in the TRA model and to separate both components into a positive and a negative dimension. It is also indicated that emotions serve as a relevant and important mediator for both WOM and social norm.

Table I shows calculated total effects on the endogenous variables, i.e. the sum of direct effect and indirect effects through the paths in the model. Based on the total effect on behavioral intention, we are able to calculate the relative contribution between PWOM and NWOM in influencing behavioral intention: PWOM 65\% and NWOM 35\%. The relative contribution between WOM (informal exchange of information) and social norm (normative social 
pressure) in influencing behavioral intention is: PWOM $50 \%$, NWOM $27 \%$, and social norm $23 \%$.

\section{The impact of WOM}

PWOM has a significant influence on behavioral attitude and intention, which supports hypotheses $\mathrm{H} 3 \mathrm{c}$ and $\mathrm{H} 3 \mathrm{~d}$. However, NWOM does not have a significant direct effect on behavioral attitude as hypothesized ( $\mathrm{H} 4 \mathrm{c}$ is rejected) and only a slight, but statistically significant, impact on behavioral intention $(\beta=-0.09 ; \mathrm{H} 4 \mathrm{~d})$.

Although NWOM does not have a significant direct effect on behavioral attitude, it does have a strong indirect effect on behavioral attitude through emotions. Figure 1 and Table I illustrate that the effect of NWOM on behavioral attitude is strong through negative emotions. The negative information consumers get about a product or a company does not influence their rational and cognitive thinking directly, only indirectly through negative emotions. This is in harmony with Sweeney et al.'s (2005) results. They find that NWOM is more emotional in nature and may result in strong and emotionally charged negative attitudes towards an organization, whereas PWOM may be more cognitive in nature and enhance cognitive attitude perceptions (Sweeney et al., 2005, 2008).

Findings also indicate that PWOM has a strong and direct positive impact on positive emotions as hypothesized ( $\beta=0.45 ; \mathrm{H} 3 \mathrm{a})$, and a slightly negative direct impact on negative emotions $(\beta=-0.25$; H3b). The opposite is valid for NWOM; NWOM has a slightly negative direct impact on positive emotions $(\beta=-0.28 ; \mathrm{H} 4 \mathrm{a})$, and a strong, positive direct impact on negative emotions $(\beta=0.57 ; \mathrm{H} 4 \mathrm{~b})$. Even though the effect of NWOM on negative emotions is twice the effect of positive emotions, this is irrelevant, since negative emotions have very little effect on behavioral attitude and intention $(\beta=-0.06$ and -0.04 , respectively). Thus, PWOM seems to boost the consumers' positive feelings towards a product and slightly reduce their negative feelings, whereas NWOM seems to slightly reduce the consumers' positive feelings towards a product and strongly increase already negative feelings towards the product. 


\begin{tabular}{lcccc}
\hline & $\begin{array}{c}\text { Positive } \\
\text { emotions }\end{array}$ & $\begin{array}{c}\text { Negative } \\
\text { emotions }\end{array}$ & $\begin{array}{c}\text { Behavioral } \\
\text { attitude }\end{array}$ & $\begin{array}{c}\text { Behavioral } \\
\text { intention }\end{array}$ \\
\hline Positive WOM (PWOM) & 0.45 & -0.25 & 0.46 & 0.46 \\
Negative WOM (NWOM) & -0.28 & 0.57 & -0.22 & -0.25 \\
Positive emotions & & & 0.66 & 0.47 \\
Negative emotions & 0.18 & -0.14 & -0.06 & -0.04 \\
Social norm & & & 0.20 & 0.21 \\
Behavioral attitude & & & & 0.71 \\
\end{tabular}

Note: Total effect is direct effect plus indirect effects (based on path coefficients in Figure 2).

Table I. Total effects on endogenous variables

Table 1 shows that the total impact of PWOM is twice the impact of NWOM on behavioral attitude ( $\beta=0.46$ and -0.22 , respectively) as well as on behavioral intention ( $\beta=0.43$ and 0.15 , respectively), i.e. PWOM is more influential than NWOM. This demonstrates asymmetric response to WOM, and tallies with the notion that PWOM has a greater effect than NWOM on consumer response, based on theories of brand loyalty and familiarity (cf. the discussion above in the section on negative and positive WOM). The studied travel agency is in fact well-known and well-established in Denmark, which leads to the expectation that PWOM will have a stronger influence than NWOM on consumer response. At the same time, it should be noted that the case study deals with a travel agency, which will tend to provide positive and exciting holiday experiences. Such experiences may create emotions such as happiness, pleasure, joy, and desires, resulting in positive associations and positive communication to others.

\section{The impact of social norm}

Social norm has significant and direct positive impacts in accordance with the four hypothesized relationships $\mathrm{H} 2 \mathrm{a}, \mathrm{H} 2 \mathrm{~b}, \mathrm{H} 2 \mathrm{c}$ and $\mathrm{H} 2 \mathrm{~d}$. Table I shows that social norm has equal effects on positive emotions, behavioral attitude and intention, and a slightly smaller effect on negative emotions ( $\beta=0.18,0.20,0.21$ and -0.14 , respectively).

\section{Comparison of the impacts of WOM and social norm}

All impacts of social norm are relatively small compared to PWOM, which indicates that PWOM has stronger total impacts than social norm on positive/negative emotions, behavioral attitude, and intention. Actually, the total effect of PWOM is more than twice the effect of social norm on both behavioral attitude (0.46 vs. 0.20$)$ and intention $(0.46$ vs. 0.21$)$. The effect of NWOM on positive and negative emotions is also considerably higher than those of social norm, indicating that NWOM has a greater total impact than social norm on emotions. On the other hand, both social norm and NWOM have almost the same level of total effect on 
behavioral attitude and intention (-0.25 and $0.21 ;-0.22$ and 0.20$)$. Thus, the relevance of including WOM in a TRA context is confirmed.

\section{The role of emotions}

The direct effects of positive and negative emotions on behavioral attitude are both significant (supporting $\mathrm{H} 7 \mathrm{a}$ and $\mathrm{H} 7 \mathrm{~b}$ ), even though negative emotions have a very low and negative impact and positive emotions have a very high and positive impact $(\beta=-0.06$ and 0.66$)$.

Table I shows that positive emotions are primarily influenced by PWOM ( $\beta=0.45)$, indicating that the travel agency Star Tour marketers should focus on PWOM rather than on reducing NWOM. On the other hand it is interesting that the negative effect of NWOM on positive emotions is relatively high $(\beta=-0.28)$, indicating that marketers should not completely ignore NWOM. Negative emotions are primarily influenced by NWOM ( $\beta=0.57)$; PWOM has a limited negative effect on negative emotions $(\beta=-0.25)$. Social norm has only a moderate impact on positive as well as negative emotions $(\beta=0.18 ;-0.14)$. These findings indicate that emotions are a mediator for both WOM and social norm; but emotions are especially important as a mediator for WOM.

\section{Conclusions}

\section{Contributions to the field}

This study looks at how WOM and emotions can be included in a TRA framework. Previous research has shown that WOM has a large impact on receivers' attitudes and buying behavior, but WOM has never been included simultaneously with social norm in one of the most recognized models within the area of consumer behavior, TRA. Our study contributes to the field in four areas.

First, previous research claims that the effect of WOM depends on whether it is positive or negative. This distinction is incorporated into the presented model and makes it possible to directly compare the effects of positive and negative WOM. Our findings clearly support the relevance of such a separation. Findings indicate that PWOM and NWOM have an asymmetric influence on all the dependent variables in the TRA model. The effect of PWOM is twice the effect of NWOM on behavioral attitude and intention, and PWOM has twice the effect on positive emotions compared to negative emotions, and vice versa for NWOM on emotions.

Second, our findings indicate that PWOM has twice the effect of social norm on behavioral attitude and intention, and that social norm and NWOM have equal levels of impact. These findings confirm that the normative influence (social norm) has a limited role compared to the positive part of the informative influence (PWOM), and it stresses the importance of separating WOM into a positive and a negative dimension and including both in the TRA model.

Third, findings also support the inclusion of both positive and negative emotions in the extended TRA model, and the fact that emotions are a mediator for especially WOM and to a lesser extent for social norm. WOM has a high impact on emotions, especially PWOM on positive emotions and NWOM on negative emotions. 
Finally, we develop a structural equation model and a measurement instrument, which provides the advantage of being able to analyze what drives WOM receivers' behavioral attitude and intention simultaneously by using PLS. High validity and reliability measures are achieved when looking at the measurement model, and high $\mathrm{R}^{2}$ values are obtained for the structural model.

\section{Limitations and future research directions}

The study focuses on only one brand. The replicability of this study's findings for other industries may be debated, since social norm, type of WOM, and emotions may be very brand or category dependent. Therefore, it is proposed that similar studies for other brands and industries be conducted.

Future studies may also look into who the preferred WOM sources are, and studies of tie strength might increase the understanding of WOM influence (Martensen and Gronholdt, 2015; Voyer and Ranaweera, 2015). Furthermore, it may be of interest also to include other variables to explain WOM effectiveness, e.g. involvement, expertise, credibility, and demographic homophily (Gilly et al., 1998; Voyer and Ranaweera, 2015). Awareness and the complexity of the decision could also be included as moderators.

\section{Acknowledgement}

Data collection was provided by M3 Research, Denmark. The authors thank for this financial support. 


\section{Appendix. Survey items}

\section{Positive WOM (PWOM)}

To what extent do you agree or disagree that other people tell you positive things about [this travel agency] (Star Tour in this study) which...

... I have not thought about before

... influence my opinion about [this travel agency] in a positive way

... help me make a decision about choosing [this travel agency]

... show me, that they are proud of having chosen [this travel agency]

To what extent do you agree or disagree that other people recommend you to choose [this travel agency]

To what extent do you agree or disagree that other people only have good things to tell you about [this travel agency]

\section{Negative WOM (NWOM)}

To what extent do you agree or disagree that other people tell you negative things about [this travel agency] which...

... I have not thought about it before

... influence my opinion about [this travel agency] in a negative way

... help me make a decision about not choosing [this travel agency]

... show me that they would never consider choosing [this travel agency]

To what extent do you agree or disagree that other people will dissuade you from choosing [this travel agency]

To what extent do you agree or disagree that other people only have bad things to tell you about [this travel agency]

\section{Positive emotions}

How suitable do you find these words in regard to your feelings for [this travel agency]?

Trust

Happiness

Satisfaction

Desirable

Pleasure

Exclusive

\section{Negative emotions}

How suitable do you find these words in regard to your feelings for this travel agency?

Irritation

Anger

Frustration

Disappointment

Boring

Regret

\section{Social norm}

Most people who are important to me find that [this travel agency] is a good choice

I would consider choosing [this travel agency] because people important to me also have chosen this travel agency

[This travel agency] is popular among people important to me 


\section{Behavioral attitude}

I have a positive attitude toward choosing [this travel agency]

[This travel agency] is a good choice for me

[This travel agency] fulfills my needs

[This travel agency] is my preferred brand among travel agencies

I like [this travel agency]

\section{Behavioral intention}

[This travel agency] will be worth considering next time I have to choose a travel agency

I will choose [this travel agency] next time I need a travel agency

I will recommend [this travel agency] to others

If you had to choose a travel agency today, how likely is it that it will be [this travel agency]?

Note: All survey items are rated on a seven-point scale: from 'strongly disagree' to 'strongly agree' (PWOM, NWOM, behavioral attitude and the first three items under behavioral intention), from 'very unlikely' to 'very likely' (the fourth item under behavioral intention) or from 'very unsuitable' to 'very suitable' (positive and negative emotions).

\section{References}

Ahluwalia, R. (2002), "How prevalent is the negativity effect in consumer environments?", Journal of Consumer Research, Vol. 29, No. 2, pp. 270-279.

Ahluwalia, R., Burnkrant, R.E., and Unnava, H.R. (2000), "Consumer response to negative publicity: The moderating role of commitment", Journal of Marketing Research, Vol. 37, No. 2, pp. 203-214.

Ajzen, I. and Fishbein, M. (1980), Understanding Attitudes and Predicting Social Behavior, Prentice Hall, Upper Saddle River, New Jersey.

Ajzen, I. (1991), "The theory of planned behavior", Organizational Behavior and Human Decision Processes, Vol. 50, pp. 179-211.

Ajzen, I. (2002), "Residual effects of past on later behavior: Habituation and reasoned action perspectives", Personality and Social Psychology Review, Vol. 6, No. 2, pp. 107-122.

Allsop, D.T., Bassett, B.R., and Hoskins, J.A. (2007), "Word of mouth: Principles and applications", Journal of Advertising Research, Vol. 47, No. 2, pp. 398-411.

Anderson, E.W. (1998), "Customer satisfaction and word of mouth", Journal of Service Research, Vol. 1, No. 1, pp. 5-17.

Arndt, J. (1967), Word of Mouth Advertising: A Review of the Literature, Research Monograph, Advertising Research Foundation, New York.

Bansal, H.S. and Voyer, P.A. (2000), "Word of mouth processes within a services purchase decision context", Journal of Service Research, Vol. 3, No. 2, pp. 166-177.

Babin. B.J., Lee, Y.-K., Kim, E.-J., and Griffin, M. (2005), "Modeling consumer satisfaction and word-of-mouth: Restaurant patronage in Korea", Journal of Services Marketing, Vol. 19, pp.133-139.

Baumgartner, H. and Homburg, C. (1996), "Applications of structural equation modeling in marketing and consumer research: A review", International Journal of Research in Marketing, Vol. 13, pp. 139-161.

Bone, P.F. (1995), "Word of mouth effects on short-term and long-term product judgements", Journal of Business Research, Vol. 32, No. 3, pp. 213-223.

Bristor, J. M. (1990), "Enhanced Explanations of Word of Mouth Communications: The Power of Relationships", Research in Consumer Behavior, Vol. 4, No. 51-83. 
Bruyn, A. De and Lilien, G.L. (2008), "A multi-stage model of word-of-mouth influence through viral marketing", International Journal of Research in Marketing, Vol. 25, No. 3, pp. 151-163.

Brown, J.J. and Reingen, P.H. (1987), "Social ties and word of mouth referral behavior", Journal of Consumer Research, Vol. 14, pp. 350-362.

Bughin, J., Doogan, J., and Vetvik, O.J. (2010), "A new way to measure word-of-mouth marketing", McKinsey Quarterly, April.

Burzynski, M.H. and Bayer, D.J. (1977), "The effect of positive and negative prior information on motion picture appreciation", Journal of Social Psychology, Vol. 101, pp. 215-18.

Carmines, E.G. and Zeller, R.A. (1979), Reliability and Validity Assessment, Sage University Paper Series on Quantitative Applications in the Social Sciences, No. 07-017. Sage, Beverly Hills, California.

Cassel, C., Hackl, P., and Westlund, A.H. (1999), "Robustness of partial least squares method for estimating latent variable quality structures", Journal of Applied Statistics, Vol. 26, No. 4, pp. 435-446.

Chakravarty, A., Young, L., and Mazumdar, T. (2010), "The differential effects of online word-of-mouth and critics' reviews on pre-release movie evaluation", Journal of Interactive Marketing, Vol. 24, No. 3, pp. 185-197.

Charlett, D. and Garland, R. (1995), “How demaging is negative word of mouth?”, Marketing Bulletin, Vol. 6, May, pp. 42-50.

Chin, W.W. (1998), "The partial least squares approach to structural equation modeling", in Marcoulides, G.A. (Ed.), Modern Methods for Business Research, Lawrence Erlbaum Associates, Mahwah, New Jersey, pp. 295-336.

Conner, M. and Armitage, C.J. (1998), "Extending the theory of planned behavior: A review and avenues for further research", Journal of Applied Social Psychology, Vol. 28, No. 15, pp. 1429-1464.

Damasio, A.R. (2000), The Feeling of What Happens: Body, Emotion and the Making of Consciousness, Vintage, London, UK.

Damasio, A.R. (2003), Looking for Spinoza: Joy, Sorrow, and the Feeling Brain, Harcourt Books, Orlando, Florida.

Dubé-Rioux. L. (1990), "The power of affective reports in predicting satisfaction judgments", in Goldberg, M.E. and Pollay, R.W. (Eds.), Advances in Consumer Research, Vol. 17, pp. 571-576, Association for Consumer Research, Provo, Utah.

Du Plessis, E. (2005), The Advertised Mind, Kogan Page, London, UK.

Dye, R. (2000), “The buzz on buzz", Harvard Business Review, Vol. 78, No. 6, pp. 139-146.

Eagly, A.H. and Chaiken, S. (1993), The Psychology of Attitudes, Harcourt Brace Jovanovich, Fort Worth, Texas.

East, R., Hammond, K., and Wright, M. (2007), "The relative incidence of positive and negative word of mouth: A multi-category study", International Journal of Research in Marketing, Vol. 24, No. 2, pp. 175-184.

Fishbein, M., and Ajzen, I. (1975), Belief, Attitude, Intention and Behavior, Addison-Wesley Publishing Company, Reading, Massachusetts.

Fiske, S.T. (1980), "Attention and weight in person perception: The impact of negative and extreme behavior", Journal of Personality and Social Psychology, Vol. 38, No. 6, pp. 889906.

Fornell, C. and Bookstein, F.L (1982), "Two structural equation models: LISREL and PLS applied to consumer exit-voice theory", Journal of Marketing Research, Vol. 19, No. 4, pp. 440-452. 
Fornell, C. and Cha, J. (1994), "Partial least squares", in Bagozzi, R.P. (Ed.), Advanced Methods of Marketing Research, Blackwell, Cambridge, Massachusetts, pp. 52-78.

Fornell, C. and Larcker, D.F. (1981), "Evaluating structural equation models with unobservable variables and measurement error", Journal of Marketing Research, Vol. 18, No. 1, pp. 39-50.

Gildin, S. Z. (2002), "Understanding the power of word-of-mouth", Revista de Administracao Mackenzie, 4, pp. 91-106.

Gilly, M.C., Graham, J.L., Wolfinbarger, M.F., and Yale, L.J. (1998), “A dyadic study of interpersonal information search", Journal of the Academy of Marketing Science, Vol. 26, No. 2, pp. 83-100.

Godes, D. and Mayzlin, D. (2004), "Using online conversation to study word-of-mouth communication”, Marketing Science, Vol. 23, No. 4, pp. 545-560.

Godin, G. and Kok, G. (1996), "The theory of planned behaviour: A review of its applications to healthrelated behaviors", American Journal of Health Promotion, Vol. 11, pp. 87-97.

Hair, J.F., Sarstedt, M., Pieper, T.M., and Ringle, C.M. (2012), "The use of partial least squares structural equation modeling in strategic management research: A review of past practices and recommendations for future applications", Long Range Planning, Vol. 45, No. 5/6, pp. 320-340.

Hansen, F. (2005), "Distinguishing between feelings and emotions in understanding communications effects", Journal of Business Research, Vol. 58, No. 10, pp. 1426-1436.

Hansen, F. and Christensen, S.R. (2007), Emotion, Advertising and Consumer Choice. Copenhagen Business School Press, Copenhagen, Denmark.

Hansen, T. (2005), "Perspectives on consumer decision making: An integrated approach", Journal of Consumer Behavior, Vol. 4, No. 6, pp. 420-437.

Hansen, T., Jensen, J.M., and Solgaard, H.S. (2004), "Predicting online grocery buying intention: a comparison of the theory of reasoned action and the theory of planned behaviour ", International Journal of Information Management, Vol. 24, pp. 539-550.

Hair, J.F., Ringle, C.M., and Sarstedt, M. (2011), "PLS-SEM: Indeed a silver bullet", Journal of Marketing Theory and Practice, Vol. 19, No. 2, pp. 139-152.

Hair, J.F., Sarstedt, M., Ringle, C.M., and Mena, J. (2012), "An assessment of the use of partial least squares structural equation modeling in marketing research", Journal of the Academy of Marketing Science, Vol. 40, No. 3, pp. 414-433.

Harrison-Walker, L.J. (2001), "The measurement of word-of-mouth communication and investigation of service quality and customer commitment as potential antecedents", Journal of Service Research, Vol. 4, No. 1, pp. 60-75.

Herr, P.M., Kardes, F.R., and Kim, J. (1991), "Effects of word of mouth and product-attribute information on persuasion: an accessibility-diagnosticity perspective", Journal of Consumer Research, Vol. 17, No 3, pp. 454-462.

Hulland, J. (1999), "Use of partial least squares (PLS) in strategic management research: A review of four recent studies", Strategic Management Journal, Vol. 20, No. 2, pp. 195204.

Kahneman, D. and Tversky, A. (1979), "Prospect theory. An analysis of decision under risk", Econometrica, Vol. 47, pp. 263-291.

Keller, E. (2007), "Unleashing the power of word of mouth: Creating brand advocacy to drive growth", Journal of Advertising Research, Vol. 47, No. 4, pp. 448-452.

Keller, E. and Fay, B. (2012), The Face-to-Face Book: Why Real Relationships Rule in a Digital Marketplace, Free Press, a division of Simon \& Schuster, New York.

Kim, M., and Hunter, J. (1993), "Relationships among attitudes, intentions and behavior", Communication Research, Vol. 20, pp. 331-364. 
Kotler, P., Keller, K.L., Brady, M., Goodman, M., and Hansen, T. (2012), Marketing Management, Second European edition, Pearson, Harlow, England.

Laczniak, R. N., DeCarlo, T. E., and Ramaswami, S. N. (2001), "Consumers' responses to negative word-of-mouth communication: An attribution theory perspective", Journal of Consumer Psychology, Vol. 11, No. 1, pp. 57-74.

Langdridge, D., Sheeran, P., and Connolly, K. (2007), "Analyzing additional variables in the theory of reasoned action", Journal of Applied Social Psychology, Vol. 37, No. 8, pp. 1884-1913

Liljander, V. and Strandvik, T. (1997), "Emotions in service satisfaction", International Journal of Service Industry Management, Vol. 8, pp. 148-169.

Mangold, W. G., Miller, F., and Brockway, G. R. (1999), "Word-of-mouth communication in the service marketplace", Journal of Services Marketing, Vol. 13, No. 1, pp. 73-89.

Martensen, A., Grønholdt, L., Bendtsen, L., and Jensen, M.J. (2007), “Application of a model for the effectiveness of event marketing", Journal of Advertising Research, Vol. 47, No. 3, pp. 283-301.

Martensen, A. and Grønholdt, L. (2008), "How events work: Understanding consumer responses to event marketing", Innovative Marketing, Vol. 4, No. 4, pp. 45-57.

Martensen, A. and Grønholdt, L. (2015), "The role of social ties in word-of-mouth effectiveness: A segmentation approach", Innovative Marketing, Vol. 11, No. 1, pp. 7-16.

Martensen, A. and Mouritsen, J. (2014), "How ad-talk and word-of-mouth influence consumers' responses", Innovative Marketing, Vol. 10, No. 2, pp. 58-69.

Mizerski, R. W. (1982), "An attribution explanation of the disproportionate influence of unfavorabl e information”, Journal of Consumer Research, Vol. 9, pp. 301-310.

Murray, K.B. and Schlacter, J.L. (1990), "The impact of services versus goods on consumers' assessment of perceived risk and variability", Journal of the Academy of Marketing Science, Vol. 18, No. 1, pp. 51-65.

Nyilasy. G. (2006), "Word of mouth: What we really know - and what we don't", in Kirby, J. and Paul Marsden, P. (Eds.), Connected Marketing: The Viral, Buzz and Word of Mouth Revolution, Elsevier, New York.

Perugini, M. and Bagozzi, R.P. (2001), "The role of desires and anticipated emotions in goaldirected behaviours: Broadening and deepening the theory of planned behavior", British Journal of Social Psychology, Vol. 40, pp. 79-98.

Phillips, D.M. and Baumgartner, H. (2002), "The role of consumption emotions in the satisfaction response", Journal of Consumer Psychology, Vol. 12, pp. 243-252.

Prendergast, G., Ko, D., and Yuen, S.Y.V. (2010), "Online word of mouth and consumer purchase intentions", International Journal of Advertising, Vol. 29, Vol. 5, pp. 687-708.

Putrevu, S. and Lord, K.R. (1994), "Comparative and noncomparative advertising: Attitudinal effects under cognitive and affective involvement conditions", Journal of Advertising, Vol. 23, No. 2, pp. 77-91.

Ringle, C., Wende, S., and Will, A. (2005), SmartPLS, Release 2.0, University of Hamburg, Hamburg, Germany. Available at: www.smartpls.de.

Sheeran, P. and Taylor, S. (1999), "Predicting intentions to use condoms: A metaanalysis and comparison of the theories of reasoned action and planned behavior", Journal of Applied Psychology, Vol. 29, pp. 1624-1675.

Shiv, B. and Fedorikhin, A. (1999), "Heart and mind in conflict: The interplay of affect and cognition in consumer decision making", Journal of Consumer Research, Vol. 26, No. 3, pp. 278-292.

Smith, R.E. and Vogt, C.A. (1995), "The effects of integrating advertising and negative word of mouth communications on message processing and response", Journal of Consumer Psychology, Vol. 4, pp. 133-151. 
Spears, N. and Singh, S.N. (2004), "Measuring attitude toward the brand and purchase intentions", Journal of Current Issues and Research in Advertising, Vol. 26, No. 2, pp. 53-66.

Sundaram, D.S., Mitra, K., and Webster, C. (1998), "Word of mouth communications: A motivational analysis", in Alba, J.W. and Hutchinson, J.W. (Eds.), Advances in Consumer Research, Association for Consumer Research, Provo, Utah, pp. 527-531.

Sweeney, J.C., Soutar, G.N., and Mazzarol, T. (2005), "Positive and negative word-of-mouth are not necessarily opposites", paper presented at the First International Conference on Word-of-Mouth Marketing, Hamburg, 6-7 October 2005, Brand Science Institute, Hamburg, Germany.

Sweeney, J.C., Soutar, G.N., and Mazzarol, T. (2008), "Factors influencing word of mouth effectiveness: receiver perspectives", European Journal of Marketing, Vol. 42, No. 3/4, pp. 344-364.

Swan, J.E., and Oliver, R.L. (1989), "Postpurchase communications by consumers", Journal of Retailing, Vol. 65, No. 4, pp. 516-533.

Söderlund, M. and Rosengren, S. (2007), "Receiving word-of-mouth from the service customer: An emotion-based effectiveness assessment", Journal of Retailing and Consumer Services, Vol. 14, pp. 123-136.

Verplanken, B., Aarts, H., van Knippenberg, A., and Moonen, A. (1998), "Habit versus planned behavior: A field experiment", British Journal of Social Psychology, Vol. 37, No. 1, pp. 111-128.

Voye, P.A. and Ranaweera, C. (2015), "The impact of word of mouth on service purchase decisions: Examining risk and the interaction of tie strength and involvement", Journal of Service Theory and Practice, Vol. 25, No. 5, pp. 636-656.

Wangenheim, F.v. (2005), "Postswitching negative word of mouth", Journal of Service Research, Vol. 8, No. 1, pp. 67-78.

Ward, J.C. and Reigen, P.H. (1990), "Sociocognative analysis of group decision making among consumers", Journal of Consumer Research, Vol. 17, No. 3, pp. 245-262.

Weber, E.U., Blais, A-R., and Tada, Y. (1998), "From Shakespeare to Spielberg: Predicting selection among modes of decision making", paper presented at the expanded version of the presidential address by Elke Weber, delivered at the 1998 Annual Meeting of the Society for Judgment and Decision Making, Dallas, Texas.

Wright, P. (1974), "The harassed decision maker: Time pressures, distractions, and the use of evidence”, Journal of Applied Psychology, Vol. 59, No. 5, pp. 555-561.

Zajonc, R.B. and Hazel, M. (1982), "Affective and Cognitive Factors in Preferences", Journal of Consumer Research, Vol. 9 (September), pp. 123-131. 